\title{
Genotypes and phylogeographical relationships of infectious hematopoietic necrosis virus in California, USA
}

\author{
Garry O. Kelley ${ }^{1}$, Christin M. Bendorf ${ }^{1}$, Susan C. Yun ${ }^{1}$, Gael Kurath ${ }^{2}$, \\ Ronald P. Hedrick ${ }^{1, *}$ \\ ${ }^{1}$ Department of Medicine and Epidemiology, School of Veterinary Medicine, University of California, Davis, \\ California 95616, USA \\ ${ }^{2}$ Western Fisheries Research Center, United States Geological Survey, Biological Resources Discipline, 6505 NE 65 th St., \\ Seattle, Washington 98115, USA
}

\begin{abstract}
Infectious hematopoietic necrosis virus (IHNV) contains 3 major genogroups in North America with discreet geographic ranges designated as upper (U), middle (M), and lower (L). A comprehensive genotyping of 237 IHNV isolates from hatchery and wild salmonids in California revealed 25 different sequence types (a to y) all in the L genogroup; specifically, the genogroup contained 14 sequence types that were unique to individual isolates as well as 11 sequence types representing 2 or more identical isolates. The most evident trend was the phylogenetic and geographical division of the L genogroup into 2 distinct subgroups designated as LI and LII. Isolates within Subgroup LI were primarily found within waterways linked to southern Oregon and northern California coastal rivers. Isolates in Subgroup LII were concentrated within inland valley watersheds that included the Sacramento River, San Joaquin River, and their tributaries. The temporal and spatial patterns of virus occurrence suggested that infections among adult Chinook salmon in the hatchery or that spawn in the river are a major source of virus potentially infecting other migrating or resident salmonids in California. Serum neutralization results of the California isolates of IHNV corroborated a temporal trend of sequence divergence; specifically, 2 progressive shifts in which more recent virus isolates represent new serotypes. A comparison of the estimates of divergence rates for Subgroup LI $\left(1 \times 10^{-5}\right.$ mutations per nucleotide site per year) indicated stasis similar to that observed in the U genogroup, while the Subgroup LII rate $\left(1 \times 10^{-3}\right.$ mutations per nucleotide site per year $)$ suggested a more active evolution similar to that of the $\mathrm{M}$ genogroup.
\end{abstract}

KEY WORDS: Infectious hematopoietic necrosis virus $\cdot$ IHNV $\cdot$ Rhabdovirus $\cdot$ Chinook salmon

\section{INTRODUCTION}

Infectious hematopoietic necrosis virus (IHNV) is a fish pathogen known to cause severe losses among young farm-reared and wild salmonids in North America and, more recently, in several countries in Europe and Asia (Wolf 1988, Winton 1991, Park et al. 1993, Enzmann et al. 2005, Nishizawa et al. 2006). The virus has been principally associated with epidemics among hatchery and farmed salmonid fish, including sockeye Oncorhynchus nerka, Chinook $O$. tshawytscha, chum O. keta, rainbow trout O. mykiss and steelhead (anadromous O. mykiss) and Atlantic salmon Salmo salar (Williams \& Amend 1976, Wolf 1988, Bootland \& Leong 1999). Since fish losses due to an IHNV outbreak may reach up to $100 \%$, control of the disease is of critical importance to commercial fish farms that produce salmon and trout for the marketplace and to state and federal hatcheries in North America that propagate salmon and steelhead for mitigation purposes. The control of IHNV in cultured salmonids has focused mainly on avoiding viral con- 
tact by using eggs from pathogen-free fish, iodophor disinfection of eggs, and by using water supplies free of the virus (Winton 1991). Newer control measures including the use of DNA vaccines offer good protection and have recently been licensed for use in Canada, but they have not been widely applied (Anderson et al. 1996, Kurath 2005, Lorenzen \& LaPatra 2005). Management of IHNV infections among wild salmon populations and salmonids once released from hatcheries requires different approaches, which may be aided by a better understanding of the genetic diversity and modes of transmission of geographically distinct viruses.

Reactivity with monoclonal antibodies, the mobility of structural proteins in polyacrylamide gels, and the ribonuclease fingerprinting and protection assays (RPA) have all been used to demonstrate genetic heterogeneity among IHNV isolates (Hsu et al. 1986, Winton et al. 1988, Ristow \& Arnzen de Avila 1991, Oshima et al. 1995, Anderson et al. 2000, Emmenegger et al. 2000). Complete or partial sequencing of the glycoprotein $(\mathrm{G})$ and non-virion (NG) genes further confirmed that distinct genetic groups of IHNV largely correlate to geographic distribution (Nichol et al. 1995, Emmenegger et al. 2000, Troyer et al. 2000, Emmenegger \& Kurath 2002, Kurath et al. 2003). Polymerase chain reaction (PCR) amplification and sequencing of a 303 nucleotide (nt) amplicon called the 'mid-G' in the G gene of IHNV has provided data useful for investigations of genetic diversity, epidemiology, and evolution of IHNV in wild and farmed salmonids (Emmenegger et al. 2000, Troyer et al. 2000, Emmenegger \& Kurath 2002, Garver et al. 2003, Kurath et al. 2003, Troyer \& Kurath 2003). These studies identified 3 major genogroups of IHNV in North America, with discreet geographic ranges (Kurath et al. 2003). IHNV isolates from the more northerly distribution of the virus most likely evolved among sockeye salmon and form a large homogenous group designated as the $\mathrm{U}$ genogroup. The geographical range of the $U$ genogroup extends from the state of Alaska, USA through the coastal regions of British Columbia, Canada, to the states of Washington and Oregon, USA (Emmenegger et al. 2000, Emmenegger \& Kurath 2002, Garver et al. 2003, Kurath et al. 2003). Troyer et al. (2000) described a second major group of IHNV, the $\mathrm{M}$ genogroup, principally circulating among rainbow trout in commercial farms in the state of Idaho, but also extending into the Columbia River basin (Garver et al. 2003). In contrast to the U genogroup, isolates within the $\mathrm{M}$ genogroup were found to be genetically heterogenous and appeared to diverge temporally into co-circulating subgroups at multiple sites (Troyer et al. 2000, Kurath et al. 2003, Troyer \& Kurath 2003). The third and final genetic group of IHNV, the L genogroup, is found principally in Chinook salmon in California and coastal watersheds of southern Oregon.

In California, the disease caused by the virus, infectious hematopoietic necrosis or IHN, was first recognized in the Sacramento River drainage in the 1950s and 1960s among juvenile Chinook salmon propagated at the Coleman National Fish Hatchery and Nimbus Hatchery (Ross et al. 1960, Parisot et al. 1965). Early investigations of variation among IHNV isolates indicated that IHNV from California differed from more northern virus isolates based on biological phenotypes (Amend et al. 1969, Mulcahy et al. 1984). IHN epidemics have continued to occur in cultured salmonids in California, and since 1990 progressive changes in serotype have been demonstrated by changes in reactivity to neutralizing antibodies in diagnostic tests (authors' unpubl. data). To date, genetic characterization of the L genogroup has been based on mid-G sequence data from 38 virus isolates from California and southern Oregon described in the overview of IHNV genetic diversity in North America by Kurath et al. (2003). That report defined 2 phylogenetic subgroups in the L genogroup, designated LI and LII, but did not consider temporal aspects or virus epidemiologic implications of the strain diversity. Recently, investigations by Bendorf et al. (in press) using viral isolates collected from a single California fish hatchery over a $35 \mathrm{yr}$ period suggested a temporal trend in divergence and corroborated the division of the L genogroup into the LI and LII subgroups. In the work described here we expand on prior studies and give a comprehensive regional study of the genetic diversity and epidemiology of IHNV throughout California and southern Oregon. Our study compares with the regional studies of IHNV throughout the geographic range such as those for the $\mathrm{U}$ and $\mathrm{M}$ genogroups in Alaska (Emmenegger et al. 2000), the Columbia River basin (Garver et al. 2003), southern Idaho (Troyer \& Kurath 2003) and coastal Washington (Emmenegger \& Kurath 2002).

Understanding the genetic heterogeneity, mutation rates, and the epidemiology of IHNV, both temporally and spatially, is critical to management decisions for fish movements and, in the future, for vaccination strategies. In the present study, we analyzed mid-G nt sequences of 237 isolates of IHNV collected in California and southern Oregon from 1966 to 2004 (see Figs. $1 \& 2$ ). This included a large set of isolates $(\mathrm{n}=$ 82) from the Feather River Hatchery described by Bendorf et al. (in press), as well as isolates from 10 additional fish hatcheries and other collection sites (Table 1), which collectively represent the most comprehensive genetic analysis to date of the $\mathrm{L}$ genogroup of IHNV. 
Table 1. Infectious hematopoietic necrosis virus (IHNV). Sequence types from California used in the present study. The isolates are grouped into sequence types designated by the letters 'a' through ' $y$ '. Grouping was based upon the sequence of a 303 nucleotide region of the $\mathrm{G}$ or glycoprotein gene of the virus. Isolation sites were Trinity River Hatchery (TR), Hoopa Fish Rearing Facility (HO), Mad River Hatchery (MA), Rowdy Creek Fish Hatchery (RC), Camp Creek (CC), and Eel River (EE). In addition, virus isolates were obtained from 11 inland sites that included Feather River (FR), Lake Oroville (LO), Nimbus Hatchery (NB), Merced River Hatchery (MC), Mokelumne River Hatchery (MK), Yuba River lower site (YL), Yuba River middle site (YM), Yuba River upper site (YU), Clear Creek (CK), Battle Creek (BC) and Coleman National Fish Hatchery (CL). Isolates were also obtained from 3 coastal watersheds from southern Oregon that included: Elk River Hatchery (ER), Sixes River (SX), and Rogue River (RR). Host fish species included Chinook (C), coho (CO), steelhead (S), and rainbow trout (R). na: not available

\begin{tabular}{|c|c|c|c|c|c|c|c|}
\hline $\begin{array}{l}\text { Sequence } \\
\text { type }\end{array}$ & $\begin{array}{c}\text { Isolate } \\
\text { no. }\end{array}$ & $\begin{array}{l}\text { Isolation } \\
\text { site(s) }\end{array}$ & $\begin{array}{l}\text { Host(s) } \\
\text { (n) }\end{array}$ & $\begin{array}{l}\text { Life stage } \\
\text { (n) }\end{array}$ & Year(s) & Source & $\begin{array}{c}\text { Accession } \\
\text { no. }\end{array}$ \\
\hline $\mathrm{a}$ & 2 & ER, FR & $\mathrm{C}(1)$ & na & 1969,1976 & Bendorf et al. (in press) & AY598415 \\
\hline $\mathrm{b}$ & 32 & $\begin{array}{c}\mathrm{CC}, \mathrm{ER}, \mathrm{FR} \\
\mathrm{HO}, \mathrm{MC}, \mathrm{RC} \\
\mathrm{RR}, \mathrm{TR}\end{array}$ & $\begin{array}{c}\mathrm{C}(26), \mathrm{S}(3) \\
\mathrm{CO}(2), \mathrm{NA}(1)\end{array}$ & $\begin{array}{l}\text { Adult (26), } \\
\text { yearling (4), } \\
\text { fry (2) }\end{array}$ & 1969-1998 & Bendorf et al. (in press) & AY598416 \\
\hline $\mathrm{C}$ & 1 & MK & $\mathrm{S}$ & Adult & 1971 & Present study & DQ910915 \\
\hline$d$ & 1 & FR & $\mathrm{C}$ & na & 1971 & Bendorf et al. (in press) & AY598417 \\
\hline $\mathrm{e}$ & 1 & NB & $\mathrm{C}$ & Adult & 1974 & Bendorf et al. (in press) & DQ910908 \\
\hline $\mathrm{f}$ & 1 & $\mathrm{TR}$ & $\mathrm{C}$ & Adult & 1991 & Bendorf et al. (in press) & DQ910909 \\
\hline g & 1 & NB & $\mathrm{C}$ & Adult & 1966 & Nichol et al. (1995) & L40881 \\
\hline $\mathrm{h}$ & 2 & $\mathrm{CL}, \mathrm{MA}$ & $\mathrm{S}(1), \mathrm{C}(1)$ & Adult (2) & 1979,1985 & Present study & DQ910916 \\
\hline $\mathrm{i}$ & 1 & CL & C & Adult & 1980 & Nichol et al. (1995) & L40873 \\
\hline $\mathrm{j}$ & 1 & TR & $\mathrm{C}$ & na & 1987 & Present study & DQ910917 \\
\hline $\mathrm{k}$ & 2 & $\mathrm{MC}, \mathrm{SX}$ & $\mathrm{C}(2)$ & $\begin{array}{c}\text { Adult (1), } \\
\text { fingerling (1) }\end{array}$ & 1986,1988 & Bendorf et al. (in press) & DQ910910 \\
\hline 1 & 1 & $\mathrm{EE}$ & $\mathrm{S}$ & Adult & 1988 & Present study & DQ910921 \\
\hline $\mathrm{m}$ & 18 & $\begin{array}{c}\mathrm{BC}, \mathrm{CL}, \mathrm{FR}, \\
\mathrm{MC}, \mathrm{NB}\end{array}$ & $\begin{array}{l}\mathrm{C}(13), \mathrm{S}(5) \\
\text { juvenile (1) }\end{array}$ & Adult (17), & $1989-2003$ & Bendorf et al. (in press) & AY598418 \\
\hline $\mathrm{n}$ & 24 & $\begin{array}{c}\mathrm{CL}, \mathrm{FR}, \mathrm{MC} \\
\mathrm{MK}, \mathrm{NB}\end{array}$ & $\mathrm{C}(22), \mathrm{S}(2)$ & Adult (24) & 1990-1999 & Bendorf et al. (in press) & AY598419 \\
\hline o & 1 & CL & $\mathrm{C}$ & Adult & 1995 & Bendorf et al. (in press) & DQ910911 \\
\hline $\mathrm{p}$ & 1 & NB & $\mathrm{C}$ & Adult & 1998 & Present study & DQ910918 \\
\hline q & 1 & CL & $\mathrm{C}$ & Adult & 2001 & Present study & DQ910922 \\
\hline $\mathrm{r}$ & 4 & $\mathrm{BC}, \mathrm{CK}$ & $\mathrm{C}(4)$ & Adult (4) & 2003 & Present study & DQ910919 \\
\hline $\mathrm{s}$ & 3 & $\mathrm{BC}, \mathrm{CK}$ & $\mathrm{C}(3)$ & Adult (3) & 2003 & Present study & DQ910920 \\
\hline $\mathrm{t}$ & 48 & $\begin{array}{l}\text { BC, CK, CL, } \\
\text { FR, MK, NB }\end{array}$ & $\mathrm{C}(37), \mathrm{S}(11)$ & $\begin{array}{l}\text { Adult (19), } \\
\text { juvenile (1), } \\
\text { fry (1) }\end{array}$ & $1996-2003$ & Bendorf et al. (in press) & AY598420 \\
\hline $\mathrm{u}$ & 80 & $\begin{array}{c}\mathrm{FR}, \mathrm{MC}, \mathrm{MK}, \\
\mathrm{NB}, \mathrm{LO}, \mathrm{YL} \\
\mathrm{YM}, \mathrm{YU}\end{array}$ & $\begin{array}{c}\mathrm{C}(70), \mathrm{S}(9) \\
\mathrm{R}(1)\end{array}$ & $\begin{array}{l}\text { Adult (71), } \\
\text { yearling (2), } \\
\text { fingerling (6) } \\
\text { fry (1) }\end{array}$ & 1999-2004 & Bendorf et al. (in press) & AY598421 \\
\hline $\mathrm{v}$ & 1 & FR & $\mathrm{C}$ & Fingerling & 2001 & Bendorf et al. (in press) & AY598422 \\
\hline $\mathrm{w}$ & 1 & FR & $\mathrm{C}$ & Fingerling & 2002 & Bendorf et al. (in press) & DQ910912 \\
\hline $\mathrm{x}$ & 8 & FR, YL & $\mathrm{C}(8)$ & Adult (8) & 2003 & Bendorf et al. (in press) & DQ910913 \\
\hline y & 1 & FR & $\mathrm{S}$ & Adult & 2004 & Bendorf et al. (in press) & DQ910914 \\
\hline
\end{tabular}

\section{MATERIALS AND METHODS}

Virus isolates. Viruses were obtained from either individual fish or pooled samples of tissues from hatchery-reared or wild fish collected at state and federal hatcheries or salmon carcasses from areas in close proximity to hatcheries where anadromous fish con- gregate to spawn. Adult fish tissues sampled included anterior kidney and spleen, or ovarian fluid. Samples were taken according to procedures described by LaPatra et al. (2001). Virus isolates were routinely examined after 2 to 4 passages in the Chinook salmon embryo (CHSE-214) or epithelioma papulosum cyprinid (EPC) cell lines (Fijan et al. 1983, Lannan et al. 
1984). The earliest virus isolate was from 1966, but most viruses examined were obtained from the mid1980s to 2004 (Fig. 1). A summary of the IHNV isolates examined in the study and the locations of origin are shown in Table 1 and Fig. 2.

IHNV isolates were obtained from 6 northern coastal sites that included Trinity River Hatchery (TR), Hoopa Fish Rearing Facility (HO), Mad River Hatchery (MA), Rowdy Creek Fish Hatchery (RC), Camp Creek (CC), and Eel River (EE). In addition, virus isolates were obtained from 11 inland sites that included Feather River (FR), Lake Oroville (LO), Nimbus Hatchery (NB), Merced River Hatchery (MC), Mokelumne River Hatchery (MK), Yuba River lower site (YL), Yuba River middle site (YM), Yuba River upper site (YU), Clear Creek (CK), Battle Creek (BC) and Coleman National Fish Hatchery (CL). Isolates were also obtained from 3 coastal watersheds from southern Oregon that included: Elk River Hatchery (ER), Sixes River (SX), and Rogue River (RR) (Fig. 2). All virus isolates are available upon request. Isolates from multiple locations with identical mid-G gene sequences were grouped together to form Sequence Types a to y, and a sequence representing each sequence type was deposited in GenBank with the accession number indicated in Table 1. Abbreviated names were given for each location and fish species that included Chinook (C), coho (CO) steelhead (S), and rainbow trout (R).

Serum neutralization. The choice of viruses for which antisera were prepared was based upon historical findings with the first antiserum (Antibody Type 1) prepared in 1988, which neutralized all California IHNV isolates tested until 1990. Upon subsequent demonstrations that newer IHNV isolates were not neutralized, the 2 additional antisera were prepared. Anti-IHNV antibodies were prepared by injections of New Zealand white rabbits with gradient-purified virus (Arkush et al. 1989). Three virus isolates (NB74C Lot 122, FR92CA 61-16, FR00CF 31) were each used to prepare antiserum with neutralizing activity to their respective viruses (Antibody Types 1, 2, and 3). Neu-

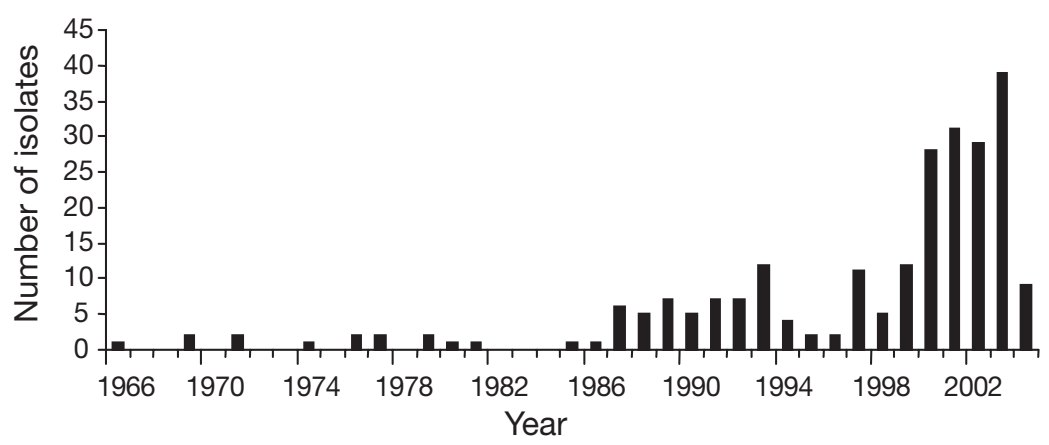

Fig. 1. Infectious hematopoietic necrosis virus (IHNV). Temporal distribution of 237 isolates found in California and southern Oregon from 1966 to 2004 tralization assays were performed by diluting each antibody (1:100) in minimal essential medium (MEM) without fetal bovine serum (FBS). Ten-fold dilution series of each IHNV isolate were mixed with an equal volume $(25 \mu \mathrm{l})$ of each diluted antibody and a negative control (MEM with control rabbit serum), and then added to 96-well plates. Plates were incubated for $1 \mathrm{~h}$ at $15^{\circ} \mathrm{C}$ with gentle mixing, after which $50 \mu \mathrm{l}$ of MEM with $2 \%$ FBS and approximately $10^{5}$ EPC cells were added to all wells. Plates were incubated at $15^{\circ} \mathrm{C}$ for a period of $10 \mathrm{~d}$ and then scored for the degree of neutralization. The neutralization index for each isolate and antibody mixture was calculated using methods described by Rovozzo \& Burke (1973).

Sequence analysis. A 303 nt region of the G gene was amplified from 119 newly obtained IHNV isolates (not including those analyzed by Bendorf et al. in press). RNA templates were extracted from cell culture supernatants, and cDNA was then generated and amplified using nested PCR with primers described by Emmenegger et al. (2000) and following methods described by Bendorf et al. (in press). Amplicons were visualized from a $1.5 \%$ agarose gel and purified using the Qiaquick PCR Purification Kit (Qiagen). Purified amplicons were sequenced on the ABI 377 automated sequencer (Applied Biosystems) using primers (Int-1: TCA CCC TGC CAG ACT CAT TGG; Int-2: ATA GAT GGA GCC TTT GTG CAT) described by Troyer \& Kurath (2003). Sequences were aligned and edited using the computer program MacDNASIS, Version 3.7 (MiraiBio), and Sequencher 4.1 (Gene Codes Corp.).

Phylogenetic reconstructions. Phylogenies were generated with the program PAUP* Version $4.0 \mathrm{~b} 10$ (Swofford 2000) and employed Neighbor-joining distance methods using Kimura's 2-parameter model (Kimura 1980). Sequence types within the phylogenetically distant $U$ and $M$ genogroups were used as outgroups for the phylograms. Statistical confidence was evaluated using 1000 bootstrap replicates (Felsenstein 1985, Hedges 1992). The maximum percent nt diversity was calculated using MEGA 2.1 (Kumar et al. 2001). The intra-genogroup nt diversity and the ratio of non-synonymous to synonymous substitutions were derived by methods described by Nei (1987) and Nei \& Gojibori (1986) using DnaSP Version 4.10.3 (Rozas \& Rozas 1999). The rates of divergence were estimated by plotting the genetic distance from the presumed L genogroup ancestor node against the year of isolation. Linear regression for the data points was generated and shown as a trend line, with the slope representing the rate of divergence within the data set as the mean number 


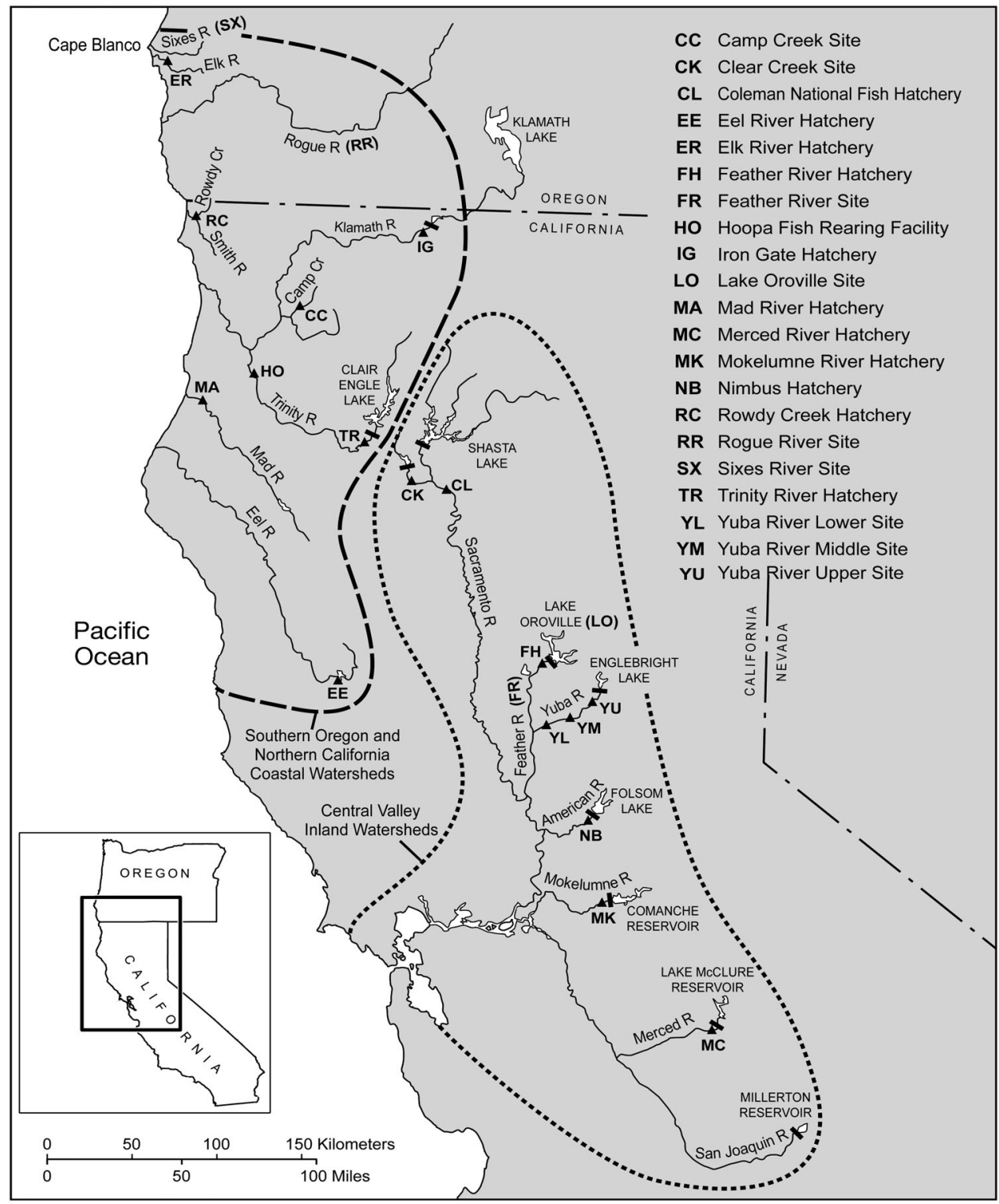

Fig. 2. Infectious hematopoietic necrosis virus (IHNV). Geographic distribution of fish hatcheries, rivers, and sample locations of the origins of the viruses used in this study. Dashed and dotted lines represent the range for the L genogroup Subgroups LI and LII, respectively. Triangles: sampling sites; rectangles: dams

of mutations per $\mathrm{nt}$ site per year. The significance $(\mathrm{p}<$ $0.05)$ of the trend line slope and the correlation coefficient $\left(\mathrm{r}^{2}\right)$ value (values at or near 1 represent a reliable trend line) were calculated using SPSS 10.0 (SPSS).

\section{RESULTS}

\section{Phylogenetic analyses}

The 119 IHNV isolates newly characterized in the present study were sequenced and analyzed in con- junction with sequences from 82 previously identified isolates from the Feather River Hatchery and Lake Oroville (Bendorf et al. in press) and 36 isolates from 8 locations in southern Oregon and northern California described by Kurath et al. (2003). Sequence analysis showed a total of 25 different mid-G sequence types (a to y) that included 14 unique types (found in only a single virus isolate) and 11 sequence types that contained 2 or more identical isolates. Phylogenies were created by using representative IHNV isolates from the $U$ and $M$ genogroups and by retaining branch nodes with bootstrap group frequencies of $>70$ 
(Fig. 3). In this standard analysis, all 25 California sequence types fell clearly within the L genogroup, which was divided into 2 distinct subgroups known as LI and LII. Sequence types inside LI and LII were present as single branches linked directly to the ancestral node for each subgroup with bootstrap support at 83 and $82 \%$, respectively. Subgroup LI contained a total of 6 virus sequence types, including 4 unique sequence types and 2 larger sequence groups identified as Types a and b. Subgroup LII contained 19 virus sequence types that fell into 10 unique sequence types and 9 major sequence groups identified as Types $\mathrm{g}$ to $\mathrm{y}$.

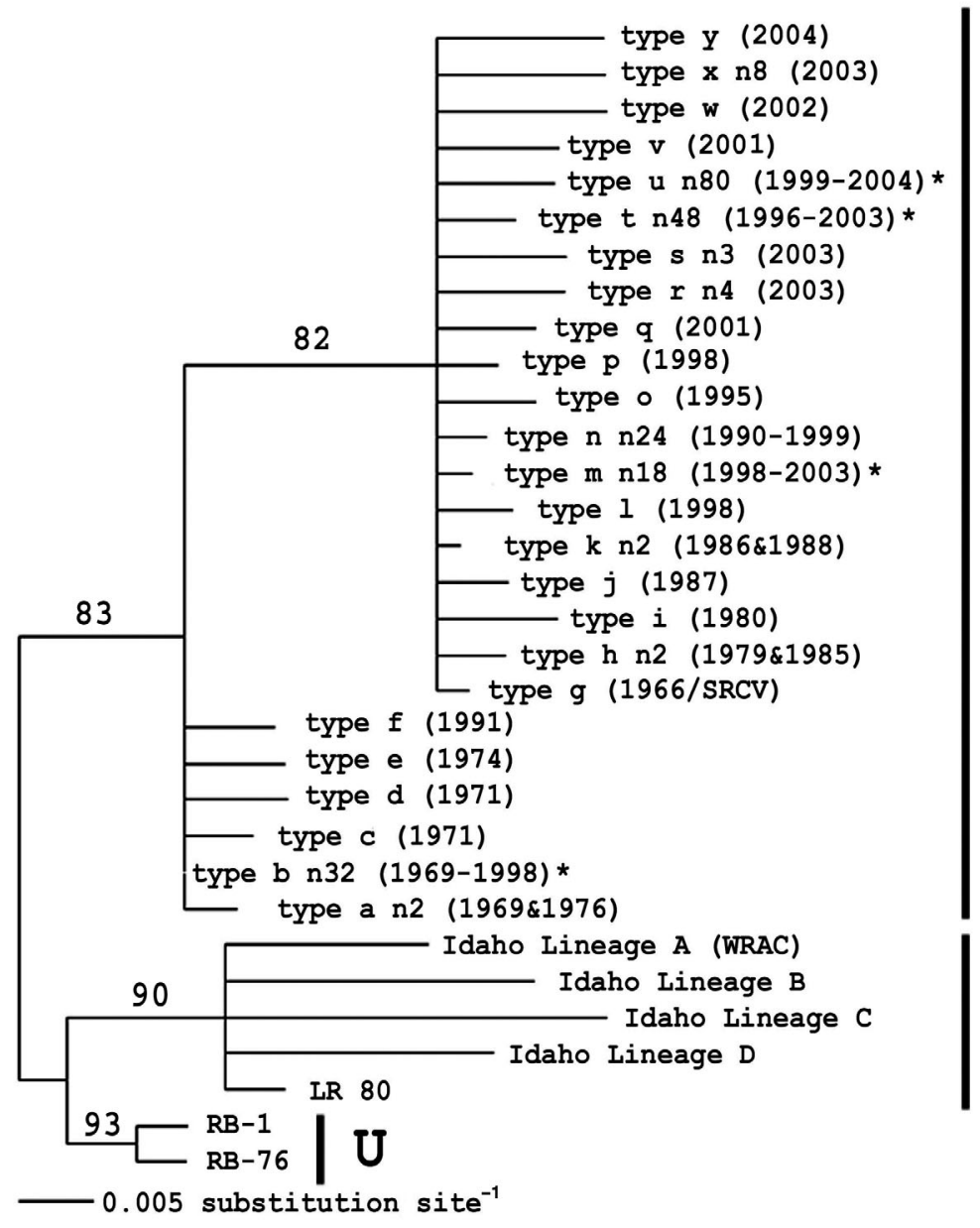

Fig. 3. Infectious hematopoietic necrosis virus (IHNV). Phylogenetic tree of mid-G gene sequences (303 nt) of virus isolates representing relationships among L, M, and U genogroups with branches retained at bootstrap group frequencies $>70$. The names for Genogroup L sequence types are shown at termi-

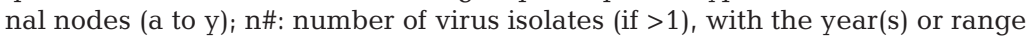
of years of isolation indicated in parentheses. The names of sequence types representing $\mathrm{U}$ and $\mathrm{M}$ genogroups, as previously described by Nichol et al. (1995), Troyer et al. (2000), and Kurath et al. (2003), were retained. Branch lengths correspond to genetic distance, and the $\mathrm{U}$ and $\mathrm{M}$ genogroups were used as outgroups. Sequence types containing an isolate found during an IHN disease outbreak are noted with an asterisk

\section{Spatial and temporal distribution of IHNV isolates}

The most revealing spatial trend was the clear separation of isolates from southern Oregon and northern California coastal watersheds from those found in the California Central Valley inland watersheds into Subgroups LI and LII, respectively (Fig. 2). Subgroup LI contained a total of 38 isolates that includes 29 and 9 isolates from coastal and inland watersheds, respectively. A total of 24 of 38 (63\%) Subgroup LI isolates were from the Trinity River Hatchery. Subgroup LII tained a total of 199 isolates (84\% of the isolates found in the present study), with only 4 isolates from coastal watersheds and 195 isolates from inland watersheds. From 1988 to the present there have been no exceptions to the geographic separation of Subgroup LI isolates in northern coastal watersheds and Subgroup LII isolates in the central valley inland drainages. Subgroup LI isolates found inland before 1988 included Sequence Type a (1 of 2 isolates), Type b (5 of 32 isolates), and Sequence Types c to e (Fig. 4A). Subgroup LII isolates found in northern coast watersheds up to 1988 included Sequence Type $h$ (1 of 2 isolates), Sequence Types $\mathrm{j}$ and 1 , and Type $\mathrm{k}$ (1 of 2 isolates) (Fig. 4B). Viral isolates within Types $\mathrm{h}$ and $\mathrm{k}$ were also found inland in 1985 and 1988, respectively (Fig. 4B). Among the Subgroup LII (inland) isolates, Sequence Type m occurred from 1989 to 2003 (Fig. 4B), with the most recent isolate taken from wild Chinook salmon spawning in Battle Creek. Type $n$ was regularly encountered in the early to mid-1990s at the Coleman National Fish Hatchery, but has not occurred since 1999. The most recent Type $r$ isolates were from Battle Creek and Clear Creek. Also in 2003, Sequence Types $s$ and $t$ were found intermingling within Battle Creek and Clear Creek. Type $\mathrm{t}$ was additionally isolated at the Nimbus, Mokelumne, Feather, and Coleman National Fish hatcheries, and consistently found from 1996 to 2003. The largest number of isolates $(\mathrm{n}=80)$ was characterized as Sequence Type $u$, which is prevalent in the Feather River drainage as well as in the Yuba River (Table 1; Bendorf et al. in press). IHNV isolates obtained since 1999 have predominantly been from Sequence Type u (Fig. 4B), including a 


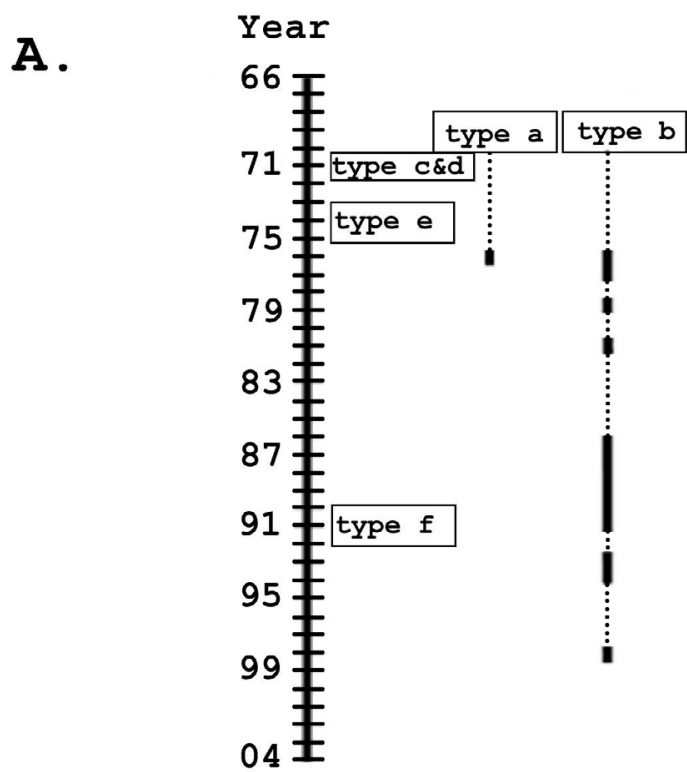

\section{LI}

B.

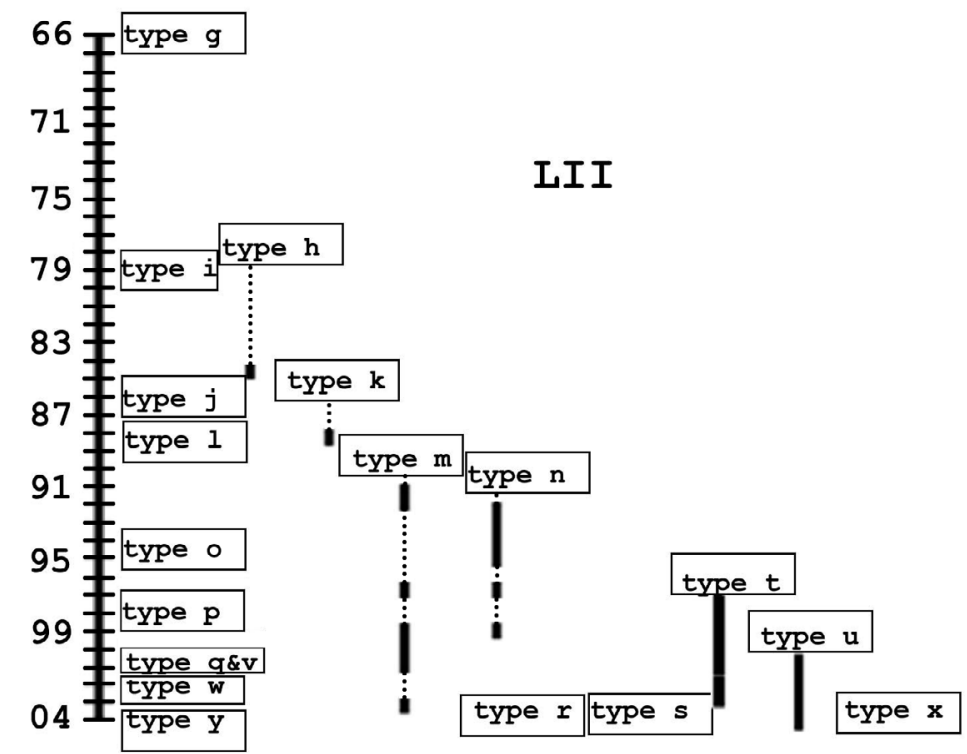

Fig. 4. Infectious hematopoietic necrosis virus (IHNV). Temporal relationships for isolates found in California and southern Oregon. Each solid black bar represents the presence of a sequence type (either unique or part of a sequence group) and dotted lines below each solid black bar indicate years the sequence type was not identified. (A) L genogroup Subgroup LI isolates shown from 1976 to 1999. (B) Subgroup LII isolates shown from 1966 to 2004

recent disease outbreak among juvenile Chinook salmon at the Mokelumne River Hatchery. The Type $v_{\text {, }}$ $\mathrm{w}, \mathrm{x}$, and $\mathrm{y}$ isolates were found only in the Feather River and Yuba River lower site and have not been observed since 2004. In addition to the foregoing temporal and spatial distributions for each sequence type found in Subgroups LI and LII, a temporal trend of divergence was evident in phlyogenetic trees when nodes were retained at bootstrap group frequencies of $>50$ (Fig. 5). Although this lower level of confidence precludes conclusions about individual relationships, this tree is presented to illustrate a notable temporal trend, with older isolates in more basal positions (e.g. Type a) and more recent isolates at the terminal nodes (e.g. Types $u, x$, and y).

\section{Antibody neutralization analyses}

Examinations of IHNV isolates with 3 rabbit antisera revealed a stepwise pattern of virus neutralization that corresponded temporally to sequence divergence as seen in phylogenetic analyses of the mid-G region (Fig. 5). Antibody 1 neutralized 64 isolates within 14 


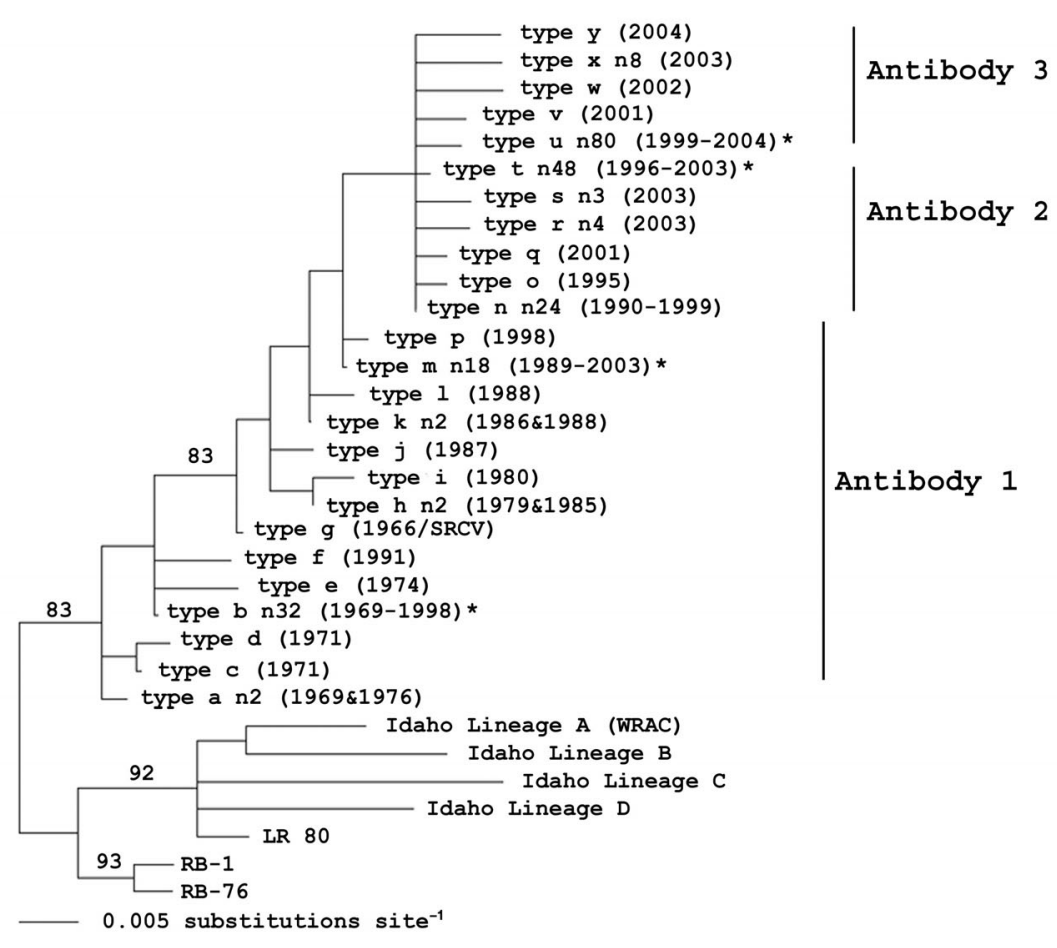

Fig. 5. Infectious hematopoietic necrosis virus (IHNV). A phylogenetic tree representing relationships among $\mathrm{L}, \mathrm{M}$, and U genogroups with branches retained at bootstrap group frequencies $>50$. This is the exact same tree shown in Fig. 3, but drawn at a lower bootstrap stringency level to illustrate temporal trends in the data. Branch lengths correspond to genetic distance, and only bootstrap values $>70$ are shown. Asterisks denote sequence types present during epizootics, and numbers $(1,2$, and 3$)$ indicate serum neutralization type

sequence types beginning with Type a and ending with Type $p$ (1966 to 2003) (Fig. 5). Antibody 2 did not neutralize any of these 64 isolates, but it effectively neutralized 81 isolates that included Types n (1990 to 1999), o (1995), q (2001), r (2003), s (2003), and t (1996 to 2003). Within the mid-G sequence region analyzed for these isolates, the only consistent change in the deduced amino acid sequence was at Position 267 of the G protein, where viral isolates reacting with Antibody 1 had glutamic acid (E) and isolates reacting with Antibody 2 had lysine (K). Antibody 3 neutralized only the remaining 91 isolates, which included Types $\mathrm{u}$ (1999 to 2004), v (2001), w (2002), x (2003), and y (2004). Isolates neutralized by Antibody 3 contained a conserved E residue at Position 297, while all other isolates had a K residue at Position 297.

\section{Genetic diversity and evolutionary rates}

A phenetic comparison of the 25 sequence types in the L genogroup found an overall maximum pairwise nt diversity of $3.9 \%$ (12 nt different out of a total of $303 \mathrm{nt}$ ) within the mid-G region analyzed. Among all isolates, the intra-genogroup nt diversity $(\pi)$ was $0.018 \pm 0.002(\pi \pm$ standard deviation) and the ratio of non-synonymous to synonymous (NS:S) mutations was 0.39 . The rate of divergence among all isolates was $1 \times 10^{-3}$ mutations per nt site per year (Fig. 6A), and the positive slope was significantly separated from zero $(p<0.0001)$. In addition, the positive slope shows the correlation $\left(\mathrm{r}^{2}=0.620\right)$ between year of isolation and the accumulation of genetic distance from the ancestral node of the L genogroup. Among the Subgroup LI isolates, the overall maximum pairwise nt diversity was $2.3 \%$ ( $7 \mathrm{nt}$ different out of a total of $303 \mathrm{nt})$. Subgroup LI had a $\pi$ of $0.010 \pm$ 0.002 , and the NS:S was 0.135 . The rate of divergence among the Subgroup LI isolates was $1 \times 10^{-5}$ mutations per nt site per year (Fig. 6B). The linear regression between year of isolation and genetic distance was not significantly different from zero $(p=0.736)$, and the association between year of isolation and genetic distance was not correlated $\left(\mathrm{r}^{2}=0.005\right)$ (Fig. 6B). In contrast, Subgroup LII isolates had overall maximum pairwise nt diversity at $3.6 \%$ (11 nt different out of a total of $303 \mathrm{nt})$, a $\pi$ of $0.013 \pm 0.001$, and the NS:S was 0.456 . The rate of divergence among the Subgroup LII isolates was $1 \times 10^{-3}$ mutations per nt site per year (Fig. 6C), and the linear regression between year of isolation and genetic distance was significantly different from zero $(\mathrm{p}<0.0001)$. The association between year of isolation and genetic distance among Subgroup LII isolates showed a weak linear relationship $\left(r^{2}=0.487\right)$ (Fig. 6C).

\section{DISCUSSION}

The distinct nature and genotypic grouping of IHNV isolates from California into the L genogroup was initially described by Kurath et al. (2003) and further supported by a recent analysis of 1 localized California study site by Bendorf et al. (in press). One of the major conclusions from the work presented here is confirmation, with a much larger and broader data set, that all, or at very least the great majority, of the IHNV in California are within the L genogroup. This genogroup represents a genetic lineage of viral isolates clearly distinct from genogroups found in the states of Alaska, Oregon, Washington, and Idaho, USA; British Columbia, Canada; and Asia and Europe (Hsu et al. 1986, 


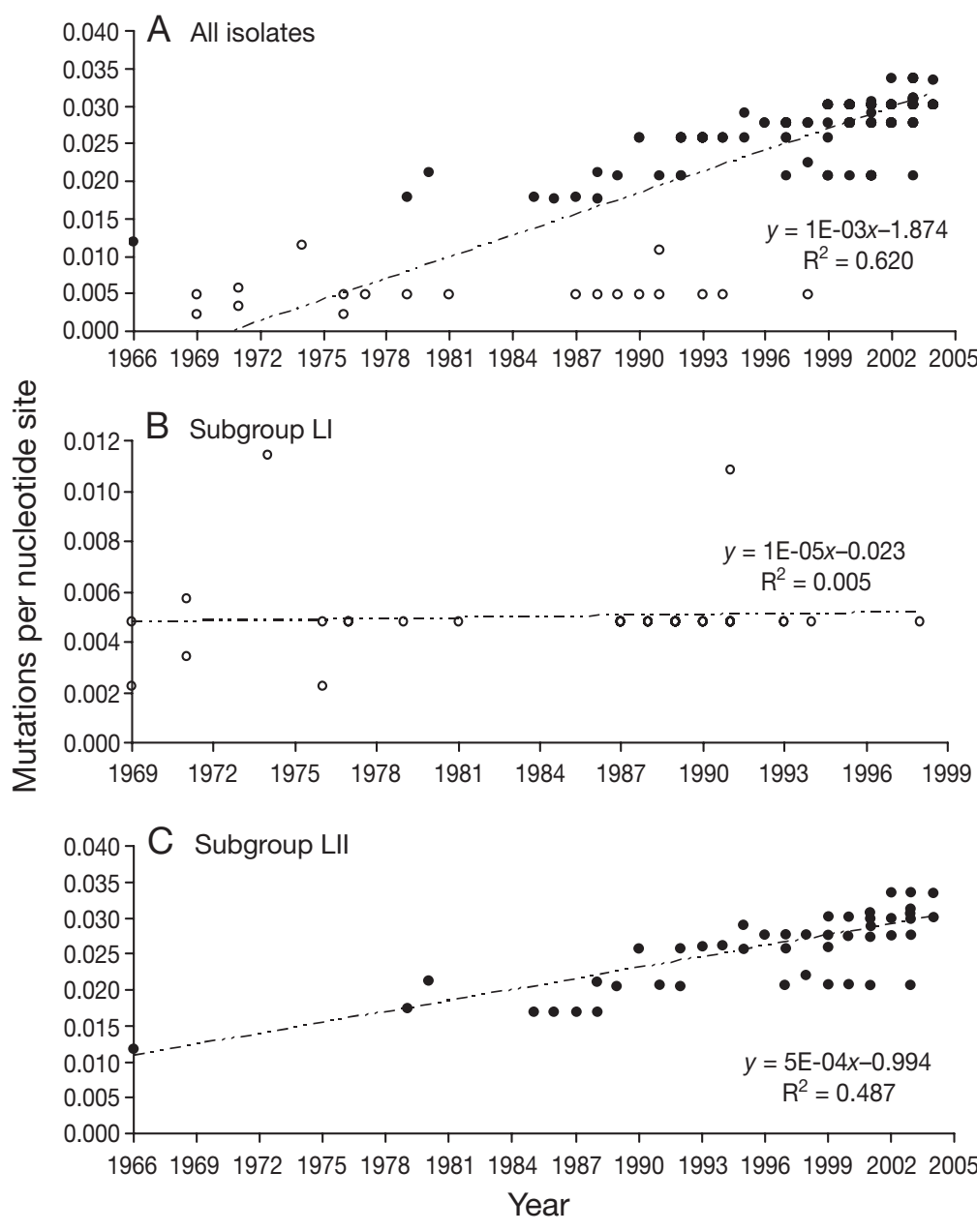

Fig. 6. Infectious hematopoietic necrosis virus (IHNV). (A) Rate of divergence for all IHNV isolates used in this study. Rate of divergence among: (B) Subgroup LI and (C) Subgroup LII isolates. Each sequence type was plotted against the genetic distance (number of substitutions per nt site per year) from the presumed ancestral isolate of the $\mathrm{L}$ genogroup. Note that the $y$-axis for (B) differs from those of (A) and (C). O: Subgroup L1; ๑: Subgroup LII

Winton 1991, Park et al. 1993, Kurath et al. 2003, Enzmann et al. 2005, Nishizawa et al. 2006). Prior studies have addressed genetic and geographical differences among a limited number of isolates from California (Hsu et al. 1986, Nichol et al. 1995, Oshima 1995, Kurath et al. 2003), but the current study is the first comprehensive phylogenetic and serotypic characterization from 20 collection sites, including 9 major salmon and steelhead fish rearing facilities within California (Table 1). The 237 IHNV isolates were separable into 25 different sequence types (a to y) of which 14 contained only a single isolate and 11 contained 2 or more identical isolates. Although isolates from steelhead, coho salmon, and rainbow trout represent a small percentage of the sample set that was dominated by isolates from Chinook salmon (84\%), there was no demonstration of strict host specificity for any of the IHNV sequence types observed in the present study.

Our phylogenetic trees (Figs. 3 \& 5) supported the clustering of the L genogroup separate from the $\mathrm{U}$ and $\mathrm{M}$ genogroup isolates as previously described (Nichol et al. 1995, Kurath et al. 2003, Bendorf et al. in press). All analyses also supported the division of the $\mathrm{L}$ genogroup into 2 major subgroups, LI and LII (Fig. 3). In our larger data set the bootstrap support for this separation of Subgroups LI and LII was 83 and $82 \%$, respectively (Fig. 3). Presence of a monophyletic ancestral node for all $\mathrm{L}$ genogroup sequence types suggested evolution of the L genogroup from a single source rather than multiple introductions. Single source origin was also presumed for $M$ genogroup isolates found in the commercial rainbow trout industry centered in the Hagerman Valley, Idaho, due to a monophyletic structure in phylogenetic analyses (Troyer et al. 2000, Garver et al. 2003). In our study, the phylogenetic tree with nodes retained at bootstrap values $>70$ (Fig. 3) did not reveal temporal trends in IHNV evolution. In contrast, the stepwise evolution of more recent isolates near the crown of the tree evolving from older isolates near the base of the tree was suggested by a less stringent tree, with nodes retained at bootstrap values $>50$. This possible temporal trend was further supported by the results of serum neutralization studies; specifically, serotypes within the L genogroup followed a stepwise pattern of evolution, with older isolates neutralized by Antibody 1, intermediate isolates from 1990 to 2004 neutralized by Antibody 2, and more contemporary isolates neutralized by Antibody 3 (Fig. 5). Although phylogenetic relationships with bootstrap values between 50 and 70 are too low to be considered conclusive, the step-wise tree topology and neutralization results suggest a hypothesis that the L genogroup has diverged directionally from an ancestor of Subgroup LI, but then evolved within Subgroup LII in response to residence in inland waters, including the Sacramento River and San Joaquin River drainages.

Although the exact mode of IHNV introduction into California remains unknown, previous studies (Kurath et al. 2003) have suggested that a host jump phenomenon occurred from a U genogroup ancestor by way of unpasteurized sockeye salmon viscera used as feed or possibly from infected eggs or transplantation of 
infected fish. If indeed a host jump from sockeye (U genogroup) to Chinook (L genogroup) occurred, then at least a 5-fold increase in the rate of viral evolution has taken place since the appearance of the first known L genogroup isolate in California. This is indicated by the overall rate of divergence found in the $\mathrm{L}$ genogroup $\left(1 \times 10^{-3} \mathrm{nt}\right.$ substitutions per site per year) (Fig. 6A), which is unlike the static pattern observed with the U genogroup $\left(2 \times 10^{-4}\right.$ nt substitutions per site per year). However, within the L genogroup the 2 subgroups differed dramatically, with the Subgroup LI $(1 \times$ $10^{-5} \mathrm{nt}$ substitutions per site per year) in apparent stasis similar to the U genogroup, and the Subgroup LII $\left(1 \times 10^{-3} \mathrm{nt}\right.$ substitutions per site per year $)$ in relatively rapid evolution similar to the $\mathrm{M}$ genogroup $\left(1.2 \times 10^{-3}\right)$ as described by Kurath et al. (2003). Kurath et al. (2003) have suggested that genetic stasis in the U genogroup may be the result of a long-term host-pathogen association in which viral fitness has reached a high level in equilibrium with the host, while $M$ genogroup viruses are evolving more rapidly due to relatively recent adaptation to a new host, rainbow trout. By this logic, the apparent stasis in LI may indicate a long-term stable host-pathogen association that persists in more northern coastal rivers, and may be an indication that LII is evolving more rapidly in the inland watersheds. Within the Subgroup LII, geographic range evaluations of the rate of divergence among viral isolates from individual watersheds demonstrated that localized differences exist (Bendorf et al. in press). In the case of the Feather River $\left(9.1 \times 10^{-4}\right)$, as much as a 3 fold increase in divergence rate was observed compared to that observed from other inland watersheds such as Battle Creek $\left(3 \times 10^{-4}\right)$ and the American River $\left(4 \times 10^{-4}\right)$ (data not shown). The total intra-genogroup nt diversity observed among all viral isolates from the L genogroup in our study ( $\pi=0.018$, mean 5.4 nt differences out of $303 \mathrm{nt}$ ) is higher than that previously reported by Kurath et al. (2003) $(\pi=0.012$, mean $3.5 \mathrm{nt}$ differences out of $303 \mathrm{nt}$ ), most likely due to the greater number of isolates characterized in the present study. Surprisingly, our total diversity is nearly identical to that found by Bendorf et al. (in press) for IHNV from a single hatchery in California over $35 \mathrm{yr}(\pi=0.017$, mean of $5.3 \mathrm{nt}$ differences out of $303 \mathrm{nt}$ ), indicating that this localized study site is nearly as diverse as the entire L genogroup range. We did not observe heterogeneity (data not shown) at nt Sites 786, 844, and 907, as shown by Garver et al. (2003), or variable amino acid residues at Positions 272 to 276, as described by Huang et al. (1996). The presence of non-synonymous mutations located at Positions 267 and 297 was consistent with the changes in neutralization type and may indicate specific mutations that are a result of immune selection pressure among the Subgroup LII sequence types. However, mutations elsewhere in the $\mathrm{G}$ protein may also be involved. Ratios of non-synonymous to synonymous mutations were 0.135 and 0.456 for Subgroup I and II, respectively, and suggest no overall positive selection pressure among isolates found in California. Although individual nt sites could still be under selection, these findings support the lack of an overall positive selection pressure, as described previously among the U, M, and L genogroups by Kurath et al. (2003).

The inland Sacramento and San Joaquin River drainages contain wild and hatchery-reared Chinook salmon that historically include 4 genetically distinct fall, late-fall, winter, and spring runs (Yoshiyama et al. 1998), and steelhead. Major rearing efforts have focused on supplementing Chinook salmon and steelhead runs considered as threatened or endangered. The presence of several large and intensive salmonid production facilities and their contribution to the transmission of IHNV between hatchery and wild fish, and the extent of spawning runs overlapping temporally are poorly understood, and were not a focal point of this study. However, our hypothesis is that moderated water flows due to intensive water management, and the resulting altered water temperatures, may contribute to the overlap among seasonal spawning runs (Yoshiyama et al. 2000), thereby perpetuating the divergence of the L genogroup by providing yearround availability of susceptible hosts. The perpetual access to infections among adult Chinook salmon in the hatchery or that spawn in the river could represent the major virus source in the system for susceptible adult immigrants and smolt out-migrants. However, laboratory studies (authors' unpubl. data) have shown that IHNV was not easily transmitted from infected Chinook salmon to cohabitant rainbow trout, which suggests that fish harboring IHNV as outmigrant juveniles may not represent a major source of virus that would infect other salmonids they might encounter in the river. Similar conclusions were reached in studies by Foott et al. (2006), who found it difficult to demonstrate fish to fish transmission of the disease between cohorts of juvenile Chinook salmon under experimental conditions. Factors such as virus amplification, occurring with the seasonal increase in susceptible fish biomass, might perpetuate divergence by allowing a specific isolate to dominate in a specific system for that year (e.g. Type r in 2000 and 2002, Type u from 2000 to 2003), and the fragmentation of host populations into individual production ponds may serve to expose a population of reservoir hosts potentially with no or insufficient immunity. Other environmental factors or stressors encountered by out-migrant Chinook salmon may be sufficient to cause young salmon to undergo virus-induced mortality, but this is difficult to assess. 
In summary, unique environmental conditions created by intensive water management, combined with high-density rearing of salmonids may have created the conditions that favor greater selection pressure (increased rate of genetic divergence) on IHNV from salmonids in California inland water sources. In contrast, a better balance between viral fitness and the environment may occur in coastal locations where Subgroup LI is present. Transmission of virus among overlapping runs of adult Chinook salmon may be the principal means by which IHNV is maintained in inland waters. Certainly, other environmental variables and the impact of large fish-rearing facilities in the inland waters would likely influence virus evolution. Studies are currently underway to build statistical models that accurately predict either subgroup or serotype based on host or environmental determinants that may influence the divergence of IHNV in California. These models may give fishery managers the predictive power to assess the risk in virus endemic areas or areas in close proximity to an IHNV endemic area; specifically, those areas that will be utilized by anadromous salmonids known to be threatened and endangered.

Acknowledgements. We kindly thank William Cox and Tresa Veek from the California Department of Fish and Game and Scott Foott and Kimberly True of the US Fish and Wildlife Service for their assistance in obtaining virus isolates. This work was supported in part by a contract with the California Department of Water Resources (4600002951) and the California Department of Fish and Game.

\section{LITERATURE CITED}

Amend DF, Yasutake WT, Mead W (1969) A hematopoietic virus disease of rainbow trout and sockeye salmon. Trans Am Fish Soc 98:796-804

Anderson ED, Mourich DV, Fahrenkrug SC, LaPatra S, Shepherd J, Leong JA (1996) Genetic immunization of rainbow trout (Oncorhynchus mykiss) against infectious hematopoietic necrosis virus. Mol Mar Biol Biotechnol 5: $114-122$

Anderson ED, Engelking HM, Emmenegger EJ, Kurath G (2000) Molecular epidemiology reveals emergence of a virulent infectious hematopoietic necrosis (IHN) virus strain in wild salmon and transmission to hatchery fish. J Aquat Anim Health 12:85-99

Arkush KD, Bovo G, de Kinkelin P, Winton JR, Wingfield WH, Hedrick RP (1989) Biochemical and antigenic properties of the first isolates of infectious hematopoietic necrosis virus from salmonid fish in Europe. J Aquat Anim Health 1:148-153

Bendorf AM, Kelley GO, Yun SC, Kurath G, Andree KB, Hedrick RP (in press) Genetic diversity of infectious hematopoietic necrosis virus (IHNV) from Feather River and Lake Oroville, California and virulence of selected isolates for Chinook salmon (Oncorhynchus tshawytscha) and rainbow trout (Oncorhynchus mykiss). J Aquat Anim Health
Bootland LM, Leong JC (1999) Infectious hematopoietic necrosis virus. In: Woo PTK, Bruno DW (eds) Fish diseases and disorders, Vol 3. CAB International, Wallingford, p 57-112

Emmenegger EJ, Kurath G (2002) Genetic characterization of infectious hematopoietic necrosis virus of coastal salmonid stocks in Washington state. J Aquat Anim Health 14: 25-34

Emmenegger EJ, Meyers TR, Burton TO, Kurath G (2000) Genetic diversity and epidemiology of infectious hematopoietic necrosis virus in Alaska. Dis Aquat Org 40:163-176

Enzmann PJ, Kurath G, Fichtner D, Bergmann SM (2005) Infectious hematopoietic necrosis virus: monophyletic origin of European isolates from North American Genogroup M. Dis Aquat Org 66:187-195

Felsenstein J (1985) Confidence limits on phylogenies: an approach using the bootstrap. Evolution 39:783-791

Fijan N, Sulimanoviã D, Bearzotti M, Muziniã D, Zwillenberg LO, Chilmonczyk S, Vautherot JF, de Kinkelin P (1983) Some properties of the epithelium papulosum cyprini (EPC) cell line from carp Cyprinus carpio. Ann Virol (Paris) 134:207-220

Foott JS, Free D, McDowell TS, Arkush KD, Hedrick RP (2006) Infectious hematopoietic necrosis virus transmission and disease among juvenile Chinook salmon exposed in culture compared to environmentally relevant conditions. San Fran Estuary Watershed Sci 4:1-16

Garver KA, Troyer RM, Kurath G (2003) Two distinct phylogenetic clades of infectious hematopoietic necrosis virus overlap within the Columbia River basin. Dis Aquat Org 55:187-203

Hedges SB (1992) The number of bootstrap replications needed for accurate estimation of the bootstrap P value in phylogenetic studies. Mol Biol Evol 9:366-369

Hsu YL, Engelking HM, Leong JC (1986) Occurrence of different types of infectious hematopoietic necrosis virus in fish. Appl Environ Microbiol 52:1353-1361

Huang C, Chien MS, Landolt M, Batts W, Winton JR (1996) Mapping the neutralizing epitopes on the glycoprotein of infectious haematopoietic necrosis virus, a fish rhabdovirus. J Gen Virol 77:3033-3040

Kimura M (1980) A simple method for estimating evolutionary rate of base substitutions through comparative studies of nucleotide sequences. J Mol Evol 16:111-120

Kumar S, Tamura K, Jakobsen IB, Nei M (2001) MEGA2: molecular evolutionary genetics analysis software. Bioinformatics 17:1244-1245

Kurath G (2005) Overview of recent DNA vaccine development for fish. In: Midtlyng PJ (ed) Progress in fish vaccinology. Dev Biol 121:201-213

Kurath G, Garver KA, Troyer RM, Emmenegger EJ, EinerJensen K, Anderson ED (2003) Phylogeography of infectious haematopoietic necrosis virus in North America. J Gen Virol 84:803-814

Lannan CN, Winton JR, Fryer JL (1984) Fish cell lines, establishment and characterization of nine cell lines from salmonids. In Vitro 20:671-678

LaPatra SE, Corbeil S, Jones GR, Shewmaker WD, Lorenzen N, Anderson ED, Kurath G (2001) Protection of rainbow trout against infectious hematopoietic necrosis virus four days after specific or semi-specific DNA vaccination. Vaccine 19:4011-4019

Lorenzen N, LaPatra SE (2005) DNA vaccines for aquacultured fish. Rev Sci Tech Off Int Epizoot 24:201-213

Mulcahy D, Pascho R, Jenes CK (1984) Comparison of in vitro growth characteristics of ten isolates of infectious haematopoietic necrosis virus. J Gen Virol 65:2199-2201 
Nei M (1987) Molecular evolutionary genetics. Columbia University Press, New York

Nei M, Gojobori T (1986) Simple methods for estimating the number of synonymous and non-synonymous nucleotide substitutions. Mol Biol Evol 3:418-426

Nichol ST, Rowe JE, Winton JR (1995) Molecular epizootiology and evolution of the glycoprotein and non-virion protein genes of infectious hematopoietic necrosis virus, a fish rhabdovirus. Virus Res 38:159-173

Nishizawa T, Kinoshita S, Kim WS, Higashi S, Yoshimizu M (2006) Nucleotide diversity of Japanese isolates of infectious hematopoietic necrosis virus (IHNV) based on the glycoprotein gene. Dis Aquat Org 71:267-272

Oshima KH, Arakawa CK, Higman KH, Landolt ML, Nichol ST, Winton JR (1995) The genetic diversity and epizootiology of infectious hematopoietic necrosis virus. Virus Res 35:123-141

Parisot TJ, Yasutake WT, Klontz GW (1965) Virus diseases of the Salmonidae in western United States. I. Etiology and epizootiology. Ann NY Acad Sci 126:502-519

Park MA, Sohn SG, Lee SD, Chun SK, Park JW, Fryer JL, Hah YC (1993) Infectious haematopoietic necrosis virus from salmonids cultured in Korea. J Fish Dis 16:471-478

Ristow SS, Arnzen de Avila J (1991) Monoclonal antibodies to the glycoprotein and nucleoprotein of infectious hematopoietic necrosis virus (IHNV) reveal differences among isolates of the virus by fluorescence, neutralization, and electrophoresis. Dis Aquat Org 11:105-115

Ross AJ, Pelnar J, Rucker RR (1960) A virus-like disease of Chinook salmon. Trans Am Fish Soc 89:160-163

Rovozzo G, Burke CN (1973) A manual of basic virological techniques. Prentice-Hall, Englewood Cliffs, NJ, p 97

Rozas J, Rozas R (1999) DNaSP Version 3, an integrated pro-

Editorial responsibility: Mark Crane,

Geelong, Victoria, Australia gram for molecular population genetics and molecular evolution analysis. Bioinformatics 15:174-175

Swofford DL (2000) PAUP* (Version 4.0). Phylogenetic analysis using parsimony ( ${ }^{*}$ and other methods). Sinauer Associates, Sunderland, MA

Troyer RM, Kurath G (2003) Molecular epidemiology of infectious hematopoietic necrosis virus reveals complex virus traffic and evolution within southern Idaho aquaculture. Dis Aquat Org 55:175-185

Troyer RM, LaPatra SE, Kurath G (2000) Genetic analyses reveal unusually high diversity of infectious haematopoietic necrosis virus in rainbow trout aquaculture. J Gen Virol 81:2823-2832

Williams IV, Amend DF (1976) A natural epizootic of infectious hematopoietic necrosis in fry of sockeye salmon (Oncorhynchus nerka) at Chilko Lake, British Columbia. J Fish Res Board Can 33:1564-1567

Winton JR (1991) Recent advances in detection and control of infectious hematopoietic necrosis virus in aquaculture. Annu Rev Fish Dis 1:83-93

Winton JR, Arakawa CK, Lannan CN, Fryer JL (1988) Neutralizing monoclonal antibodies recognize antigenic variants among isolates of infectious hematopoietic necrosis virus. Dis Aquat Org 4:199-204

Wolf K (1988) Infectious hematopoietic necrosis virus. In: Fish viruses and fish viral diseases. Cornell University Press, Ithaca, NY, p 83-114

Yoshiyama RM, Fisher FW, Moyle PB (1998) Historical abundance and decline of Chinook salmon in the central valley region of California. North Am J Fish Manage 18:487-521

Yoshiyama RM, Moyle PB, Gerstung ER, Fisher FW (2000) Chinook salmon in the California Central Valley: an assessment. Fisheries 15:6-20

Submitted: January 19, 2007; Accepted: April 10, 2007

Proofs received from author(s): August 4, 2007 